\title{
(Re)distribution and Growth: What is the Role of Social Protection?
}

\author{
Rachel Sabates-Wheeler and Gabriele Koehler
}

\begin{abstract}
Considerations of social justice, as opposed to growth, must provide the linchpin of a social protection agenda because the chronically vulnerable and poor are typically in their predicament because of institutionalised patterns of disadvantage. Furthermore, if the primary purpose of social protection programming is to transform the lives of large numbers of vulnerable people, only a radical agenda based on considerations of (re)distribution, recognition and representation will suffice, precisely because resource transfers alone (including provision of assets or jobs) will not be able to transform the terms of engagement upon which the vulnerable and poor interface with society.
\end{abstract}

As an introduction to a set of articles that cohere to emphasise the importance of justice, inclusion, redistribution and rights in social protection programming, we reflect here on a number of the bigger issues that continue to thwart political commitment to progressive distributional objectives within the social protection and growth agendas. As van Ginneken (this IDS Bulletin) argues, 'the global economy produces huge benefits, which are [however] distributed very unequally both between and within countries'.

It is refreshing to see the (new) macro-growth agenda reflect and recognise the importance of context-specificity and policy combinations as central to identifying a path to poverty reduction (Ravallion 2007; Rodrik 2007; Hausmann et al. 2008). What remains problematic, however, particularly when viewed through a social protection lens, are: (1) the continuing explicit assumption that economic growth considerations should prevail over considerations of justice as a recipe for poverty reduction; (2) the lack of real attention paid to the advantages of redistribution; and (3) the disregard of political, institutional and 'human' factors sustaining persistent inequalities.

\section{Growth or justice?}

The implications of the new growth agenda for social protection translate into 'more of the same' (Ravallion 2007): driven by instruments projectised and individualised rather than socially led, and distributive and palliative rather than redistributive and transformative. It is true that instruments at scale, such as cash transfers, can be a 'good thing' especially for alleviating poverty (as pointed out by Koehler, in this IDS Bulletin), but they have limited value within a long-term progressive change model. For instance, vulnerability to negative outcomes for poorer people is, on average, very high compared to nonpoor and dominant groups. The causes of some of these vulnerabilities are, for the fortunate few, remedied by the provision of productive assets or concrete economic opportunities (e.g. decent work or business support) that can be provided in line with pro-poor programmes. For the majority, however, the remedies only partially result from physical provisions and support. While income from employment and productive assets are important, the constraints that maintain deficits for the majority are by nature economic, social, cultural and political. Recognising vulnerability as embedded in economic and social institutions and structures takes us squarely into considerations of justice. As so aptly expressed by Fraser (2005: 378):

For me, a theory of justice... should allow us to evaluate social arrangements from the perspective of one limited, but extremely important angle: how fair or unfair are the terms of interaction that are institutionalised in the society? Does the society's structural- 
institutional framework, which sets the ground rules for social interaction, permit all to participate as peers in social interaction? Or does it institutionalise patterns of advantage and disadvantage that systematically prevent some people from participating on terms of parity? Do the society's institutionalised patterns of cultural value create status hierarchies, which impede parity of participation? Does its economic structure create class stratification, which also forecloses the possibility of parity?

The fundamental question for social protection programming is then: How can social protection address and overcome entrenched inequalities, so as to enable the potential gains from growth to be inclusive and transformative?

\section{Social protection and redistribution}

Social protection should be a vehicle for (re)distribution, especially when we think of the scale of the issue and the number of individuals and households that are to be moved out of poverty and vulnerability through donor- and government-funded programmes. However, redistribution is barely mentioned within current social protection discourse. Redistribution - both as an ideological response to physical asset inequality as well as a leftist approach to changing the structure and nature of growth itself - has all but fallen off international and national policy dialogues or academic research agendas. Enclaves of interest linger, such as work by Cornia, UN DESA (2009), the OECD DAG PovNet (OECD 2009), World Institute for Development

Economics Research (WIDER) and the persistent appeal from Sir Tony Atkinson (1997) to 'bring redistribution in from the cold'. However, with the rise of the Millennium Development Goal (MDG) agenda, inequality and its policy responses have been dwarfed as one-dimensional poverty reduction has taken centre-stage.

The novelty of the 1970s Redistribution With Growth agenda (influenced enormously by IDS) was to take on the idea that redistribution has to be 'ideological': it argued that redistribution could, and should, be achieved by changing the structure and nature of growth in favour of the poor. Unfortunately, the prescriptions for a propoor growth agenda have failed miserably in achieving a more equitable distribution, on a number of grounds.
1 Poverty (in the income sense) has only declined on a global level due to advances in China and a handful of other countries. In the majority of countries, poverty has remained the same or worsened. (For example, the number of people living on less than $\$ 1.25$ per day between 1999 and 2005 actually increased from 589 to 596 million in South Asia and from 383 to 388 million in sub-Saharan Africa, despite percentage declines (UN DESA 2009: 16).

2 Growth (in neoliberal orthodoxy) ignores distribution. We know from recent empirical studies that the majority of positive growth spells over a 15-year period (1984-2001) have been anti-poor, while spells that have been propoor were characterised by negative growth.

3 Growth has not resulted in additional employment and decent work (ILO 2011), which is the lynchpin in overcoming poverty and exclusion.

4 An obsessive focus on increasing growth rates rather than changing the structure of growth is unrealistic as an approach to achieving longterm sustainable and equitable development.

For these reasons we would strongly urge a reconsideration of redistribution as a research and policy agenda. However, a return to redistribution alone is not enough. Redistribution is not politically sustainable as a social justice project unless it simultaneously considers how power both shapes the quality of social relationships and the framing of policy problems. The themes of recognition, social inclusion, representation and rights introduce to the redistribution agenda an understanding of power as relational, rather than as individual capability or a finite resource.

\section{Addressing persistent inequality}

An agenda of recognition brings to the foreground relationships - both as explanatory concept and as desirable practice. It shifts the focus from the allocation of perceived scarce resources among differently labelled categories of people to a consideration of how best to support equitable relationships between people. The relational emphasis is about building a socially inclusive society based on a diversity of identities and interests. It speaks to the representation agenda through a concern for creating the space and opportunity for different groups within 
society to find and express their voice. Successful redistribution and social protection policies could be achieved through a threefold combination of visioning, planning and deliberate decisionmaking that tackles vulnerability and poverty. This would require modalities for genuine and active participation in collective action and problem-solving, and policy space and resources enabling open-ended and challenging agendas to come to the fore, perhaps captured by what Carroll (this IDS Bulletin) terms an 'alternative national development strategy'.

Indeed, the four articles in this section point in this direction. Carroll discusses the centrality of inequalities - income inequality as well as gender, class, caste, geography and ethnicity and makes the case for integrating social protection intrinsically into national development strategies. Her concept of development strategies would transcend current practice and be founded on principles of selfreliant growth, ecological justice, gender equality and the recognition of the care economy, and most prominently, wealth redistribution. She makes the case for citizen-led planning that would integrate 'transformative and redistributive social protection systems' into such alternative national development strategies.

Koehler and Ehmke (this IDS Bulletin) each use examples from South Asia to argue for transformative forms of social protection. Koehler identifies transformative angles in government schemes introduced in the form of

\section{References}

Atkinson, A.B. (1997) 'Bringing Income Redistribution in from the Cold', Economic Journal 107: 297-321

Fraser, N. (2005) 'Mapping the Feminist Imagination: From Redistribution to Recognition to Representation', Constellations 12.3: 295-307

Hausmann, R.; Rodrik, D. and Velasco, A. (2008) 'Growth Diagnostics', in J. Stiglitz and N. Serra (eds), The Washington Consensus Reconsidered: Towards a New Global Governance, New York: Oxford University Press

ILO (2011) Global Employment Trends 2011. The Challenge of a Jobs Recovery, Geneva:

International Labour Organization cash transfers and employment guarantees. She offers for reflection a set of criteria that would constitute transformative forms of social protection. Ehmke traces the history of India's welfare regime and analyses the contradictory outcomes from 'political' or interest group-led society versus 'civil' society - the community of all citizens. The predominance of political decisions, as opposed to rights-based citizens' decisions, has resulted in a fragmented rather than universalist, socially just system of social protection. Ehmke nevertheless sees a change towards policies oriented to social justice in recent political developments in India and argues (similar to Carroll and Koehler) for full recognition and participation of citizens in decision-making.

For van Ginneken, as for Carroll, the 'Social Protection Floor' - a minimum income guaranteed through social transfers combined with access to at least basic social services provides the cornerstone of a redistributive, rights-based social justice vision. In making the case for a justiciable social protection floor, van Ginneken posits the four main human rights principles - equality and non-discrimination, participation, transparency and access to information, and accountability. He links these principles to the MDGs and shows how they need to inform the next round of MDGs so as to create a new global contract between high-, middle- and low-income countries, as well as between national governments and their citizens, which conveys the notion of social justice that this section (and this issue of the IDS Bulletin) is all about.

OECD (2009) 'Making Economic Growth More Pro-Poor: The Role of Employment and Social Protection', draft policy statement, DAC Network on Poverty Reduction (POVNET), Paris: Development Co-operation Directorate (DCD)/Development Assistance Committee (DAG)/POVNET

Ravallion (2007) 'Inequality is Bad for the Poor', in S. Jenkins and J. Micklewright (eds),

Inequality and Poverty Re-examined, New York: Oxford University Press

Rodrik (2007) One Economics, Many Recipes: Globalization, Institutions, and Economic Growth, Princeton: Princeton University Press UN DESA (2009) Rethinking Poverty. Report on the World Social Situation 2010, New York: United Nations 